\title{
PLAGUE AND OTTOMAN MEDICAL THOUGHT
}

\section{INTRODUCTION}

Although both Ottoman and European religious leaders often sanctioned the fight against epidemic diseases from the sixteenth century onwards, the Europeans undoubtedly adopted quarantine long before the Ottomans. Renaissance writers from Boccaccio to Fracastoro wrote of the contagious nature of plague, and a number of Italian city-states established quarantines as early as the fifteenth century to isolate those sick with plague. ${ }^{1}$ Other European states - particularly maritime powers like England and France - adopted the institution during the sixteenth to the eighteenth centuries. London's great plague of 1665 and the Marseilles outbreak in 1720 convinced many of the need to more strictly enforce isolation measures in order to protect people from exposure to deadly diseases from overseas. Even expatriate merchant communities from these countries sought to avoid plague in the Ottoman cities of Cairo, Smyrna and Istanbul by quietly implementing their own quarantines there. ${ }^{2}$

Yet the differences between the Ottomans and the European maritime powers were much more subtle than first meets the eye. Ottomans and other Middle Eastern Muslim plague treatise writers from 1347 to 1600 did not fundamentally differ from their western European counterparts. Both Europeans and Muslims often understood plague in contagionist terms and circulated their works in narrow courtly or academic circles. In fact, European and Muslim scholars would often interact in a way that made it hard to differentiate between the two 'civilisations', as they freely borrowed new concepts, experiences and comparative models from each other.

The gap between the European and Ottoman Muslim perceptions of plague 
only occurred between 1600 and 1800 with the rise of mercantilism and overseas commercial development in north-western Europe. Institutional reforms like quarantine came as a result of a state-led programme of economic development and radical social change, beginning with maritime states such as England. English plague treatise writers in particular participated in this evolving system. One witnesses fundamental changes in both their social context - an emerging commercial print culture - and ideological content - the mercantilist economic values of their works. In short, they would become new willing contributors to a national economic agenda that would justify mercantilist reform in the name of public health.

Strikingly, the Ottomans did not directly respond to the newer European quarantine and mercantilist discourse until after 1800, when plague treatise writers like Hamdan began to call for reform. The Ottoman government simply did not implement a state-led modernisation programme, much less a quarantine. There were comparatively fewer seventeenth- and eighteenth-century Ottoman plague treatise writers than in the sixteenth century, although they too remained limited to courtly and academic circles. Thus, unlike their English colleagues, they did not participate in print culture or reflect new commercial interests. Nevertheless, their differences with mercantilist plague treatise writers were more economic than cultural, as they, like their sixteenth-century predecessors, remained receptive to new ideas and innovations. The Ottomans had a continued commitment to proactive measures directed at protecting health, and had at least a limited discourse with the outside world. Still, European mercantilist success would eventually pressure the Ottomans by exposing them to new commercial and military threats. Commercially, the new mercantilist powers, especially England, would disrupt the Ottoman economy and even threaten its sovereignty in the name of modern, western European public health. Politically, this ideological threat would lead to growing demands for the empire's partition and colonisation.

\section{EARLY MEDICAL CONTRIBUTIONS}

Scholars have argued that western Europeans had responded differently to plague than their Muslim counterparts ever since the initial 1347-8 outbreak. The first evidence they point to is Europe's popular reaction to plague as a contagious disease. ${ }^{3}$ Boccaccio, who wrote his famous Decameron in the immediate aftermath of the Black Death in Florence summed up this attitude:

What gave more virulence to this plague, was that, by being communicated from the sick to the hale, it spread daily, like fire, when it comes in contact with large 
masses of combustibles. Nor was it caught only by conversing with, or coming near the sick, but even by touching their clothes, or anything that they had touched before. ${ }^{4}$

As a result, people '[avoided] the sick, and everything that had been near them ... Others ... in greater numbers left the city, their houses, relations and effects, and fled into the country'. Boccaccio decried these practices as utterly inhumane, since the sick and poor were often left to fend for themselves, without proper care, food and water. He believed that many died needlessly as a result. ${ }^{5}$

Most scholars see the establishment of quarantines in places like Florence and other Italian city-states within a generation of the 1347-8 outbreak as a natural response to these threats to the social order. Containing the disease within restricted areas, such as boats and guarded hospital wards, where plague victims could be isolated but cared for, seemed to resolve the problem. ${ }^{6}$

Most historians of the plague admit, albeit reticently, that early modern medical thinkers generally did not accept such notions. Instead, they, like a number of their Muslim colleagues, came to a different consensus about the plague's causes, preventive measures and cures. In their opinion, plague was originally a corruption of the air that disturbed all creatures' natural humoral balance. Earthquakes, fetid water, rotten corpses, a southerly wind or intemperate weather could all cause the ill-wind to blow, forcing frogs, rats, insects and birds to flee and striking down all who remained. Once a victim breathed in the poisonous air, the heart, the chief organ of the body, would overheat and lead to a mortal fever. The victim would display a variety of other agonising symptoms before death, including headache, light-headedness, sore throat, buboes, coughing up blood, profuse sweating, pain and discolouration on the side, the armpits and the groin. ${ }^{7}$

The medical writers also prescribed uniform preventive measures and recommended specific dietary measures that would strengthen one's humoral balance and the heart, such as figs, dates, raisins, nuts, pomegranates, light white wine and fresh spring water. They prohibited certain foods, such as leguminous vegetables, meat, milk and fish since they were prone to spoil quickly, and were affected to a much greater degree by the corrupt air. ${ }^{8}$

Furthermore, the writers believed that one could prevent plague by changing the environment. They believed, for instance, that those who sought higher ground could avoid plague, since the corrupt air tended to remain in low places. Those who had to stay in affected areas could still burn incense or dry, aromatic wood and herbs. Additionally, people should avoid bathing, as this would open one's pores to the moist, sickly air. 
Cures were also aimed at restoring the victim's humoral balance, although the writers conceded that these were desperate measures. They included bloodletting or 'cupping', classical medical ingredients like rose water, vinegar, lemon, Armenian earth and spices like black pepper. ${ }^{9}$

Historians of medicine ironically note that Al-Khatimah and Al-Khatib, both Muslim writers from the Umayyad kingdom of Granada, would be among the first medical thinkers to mention the contagious nature of the disease. Like Boccaccio, both Al-Khatimah and Al-Khatib wrote their works in the immediate aftermath of 1347-8. Al-Khatimah, wrote, for instance, about his own personal encounters with the plague:

The best which long experience has taught me is that when anyone comes into contact with a sick man, forthwith the same disease seizes him, with the same symptoms; if the first sick man has spit blood, he also spits it; if the former was hoarse, he likewise becomes hoarse; if with the first buboes appeared on the groin, so do like buboes appear in the same place with the other; if with the first a boil arose, there arises with the second in a like boil; also the second sick man carries the sickness on farther. The family suffers in the same way, shows the same symptoms; if the sickness of one member runs a fatal course, the others suffer the same fate; if the sick man is saved, so they also escaped death. In this way on the whole, with slight differences, has it gone in our city. ${ }^{10}$

However, Al-Khatimah would later go on to deny the contagious nature of disease, since he contended that contagion was contrary to Islamic law. Historians cite this reversal as a key point in the history of medicine, as it showed that Muslim religious orthodoxy stifled the development of critical, experimental thought. ${ }^{11}$

Al-Khatib, a friend and close companion to Al-Khatimah, heartedly objected to such restrictions:

If one asks 'How can you admit the assertion there is infection, when the revealed word denies this?' We answer: that infection exists, [and] is confirmed by experience, research, insight, observation and through constantly recurring accounts. These are the elements of proof. For him who has treated or recognised this case, it cannot remain concealed that mostly the man who has had contact with a patient infected with this disease must die, and that, on the other hand, the man who has had no contact remains healthy. So it is with the appearance of the illness in a house or quarter because of a garment or a vessel; even an earring can destroy him who puts it in his ear, and all the inhabitants of the house. $^{12}$ 
European writers, beginning with Fracastoro, picked up on these ideas in the sixteenth and seventeenth centuries. Fracastoro argued specifically that 'seeds of contagion' were responsible for the spread of the plague, and not just moist, corrupt air that passed from person to person. Modern authors judged that Fracastoro's prediction that germs were responsible for the spread of disease presaged the end of the Galenic system of thought.

Many scholars also see Fracastoro as an almost revolutionary figure who bridged the gap between popular contagionism and literary elites, and led future generations of medical thinkers to directly participate in formulating quarantines and other related public health policy reforms. They also point to Fracastoro's use of new inventions, such as the printing press, to disseminate his contagionist ideas. These developments, in turn, helped early modern states to extend their social control over the population, and in the process, helped to generate commercial development. ${ }^{13}$

These arguments beg careful reconsideration. First of all, it is not clear what connections Fracastoro had with his quarantinist contemporaries. Fracastoro's works did appear at a time when Italian city-states such as Venice and Florence had quarantines. However, the expansion of the quarantines to urban bureaucracies specifically dedicated to epidemic control, permanent plague hospitals (lazarettos) and cadastral registers of the dead began only some fifty years after his death, at a time when maritime states sought greater economic and social control over their populations. Fracastoro's claims may have been popular among academic circles in northern Italy and southern Germany, but they did not spur debate between quarantine officials and the Italian commercial elites who, facing new expenses and restrictions on their Mediterranean overseas trade, may have opposed them. ${ }^{14}$

Despite these limitations, historians contrast the dynamic growth of contagionist thought with Muslim writers, whom they contend simply ignored Al-Khatimah's and Al-Khatib's initial accounts. At best, Muslim writers restated Galenic maxims about the miasmatic and humoral origins of the plague, and, at worst, followed Al-Khatimah's lead in repressing medical thought in the name of religious dogmatism. ${ }^{15}$ Yet to date there has been little serious consideration of what this 'second generation' of Muslim scholars, the bulk of whom were late fifteenth- and sixteenth-century patrons of the Ottoman court, actually wrote about the plague.

There is a remarkable amount of contagionist and innovative thought among these writers, however. For instance, Bitlisi wrote prior to Fracastoro in around 1500 that plague and other diseases were contagious:

Plague is spread by smelling, touching and seeing. This contagion is similar to what happens with rabies among dogs and other animals. With rabies, dogs 
spread the disease by biting others. As I have seen by experience, rabies also spread just by touching and breathing. ${ }^{16}$

This passage is especially significant as Bitlisi grounded his assertion in his own experience, not just what he read. This cuts against the argument that Muslim authors either repeated Galenic maxims or rejected scientific innovation.

Other authors supported their own observations with attributions to earlier Muslim writers. Bitlisi, an anonymous seventeenth-century Ottoman writer and Osman, a late eighteenth-century anti-contagionist critic, claimed that Muslim doctors long considered plague to be one of the great contagious diseases, a status shared with leprosy, mange, fetid breath, measles and smallpox. Similarly, Al-Yahudi, a late fifteenth-century Jewish convert to Islam who fled to the Ottoman court, asserted that Avicenna personally witnessed the contagious nature of plague. He also said that 'Ibn Rüshd [Avveroes] of Cordoba mentions that a person who isolates himself can avoid plague'. This raises the curious argument that even key twelfth-century Islamic thinkers could presage the idea of a quarantine some two hundred years before the Black Death. Perhaps Al-Yahudi sought to cover his own personal arguments - like his warning 'not go in crowded districts' - with earlier renowned authorities so that his recommendations would be accepted within literary Islamic traditions. ${ }^{17}$

Most early modern Ottoman treatise writers advocated fleeing as a measure to avoid plague. As seen in Chapter 2, Bitlisi's own work is an extended Islamic legal justification of his own flight from a plague outbreak in Damascus and parts of Anatolia when he was returning from a pilgrimage from Mecca. ${ }^{18}$ Al-Yahudi scrupulously avoided such legal arguments, and accepted the 'most experienced Christian physicians' suggestion to flee from a plague infested area' since 'even the birds and animals cannot endure'.

Al-Yahudi and the other early modern Ottoman writers made some provocative prescriptions as cures for the plague. Al-Yahudi stated a number of times that wine was a good remedy, without mentioning that Islamic jurists almost universally condemned consuming alcohol, and wine in particular. The seventeenth-century anonymous author made a similar suggestion. Al-Yahudi also mentioned that Avicenna prescribed plague victims to drink a Venetian treacle, a complex concoction that also included alcohol and snake blood, both prohibited by Islamic law. Al-Yahudi disagreed, but only because he did not see it as effective in practice. ${ }^{19}$

Other authors also made surprising prescriptions. An anonymous seventeenth-century prescription collection included opium and sulphuric acid among its ingredients, alongside the more traditional garlic, onion, vinegar and rose water. ${ }^{20}$ Such chemicals were hardly the rule for 'traditional' Galenic 
medicine. Moreover, Bitlisi went so far as to suggest the use of quicksilver, a chemical that came into vogue in Europe at roughly the same time that he wrote his work. Bitlisi mentioned that he not only used the drug for plague during an outbreak in Diyarbekir, but also even earlier when the first syphilis pandemic broke out in Europe in 1494:

It [syphilis] was not heard of by our ancestors or from earlier philosophers. The above-mentioned disease appeared in European lands (efrenc). Since Anatolia is close to Europe, it spread from the latter to the Arab, Persian, Indian and Chinese lands. It was called 'ceb-i efrenc' due to its origin. It is now called 'frangi'. Many people died among the Muslims. The medication which was prescribed during this outbreak was unknown previously to physicians and philosophers and was not cited in medical books. The medication included melted quicksilver (erbak-i mahlul). A number of another chemicals and elements are mixed with melted quicksilver to produce the medication. I even used this drug for four months and was cured because of it. ${ }^{21}$

Bitlisi's advocacy of chemical prescriptions was freely borrowed from his European contemporaries and not from previous authorities. ${ }^{22}$

The first modern Muslim reformists were often dismissive of Bitlisi and the early Ottoman plague writers, claiming that the audience and impact of this literature was minimal. Such views were very important, as they justified the claims of later historians that the Ottomans did nothing substantial about plague and other epidemic diseases until the reforms of the 1830s. Sultan Mahmud II's eloquently expressed this argument when he gave his inaugural address for the empire's first European-style medical school in 1835:

It is true that many books were written among us [Muslims] on medical sciences and that the Europeans even learned many things by translating these books into their own languages. The books were written in Arabic, however, and, as they ceased to be objects of interest and care in the Muslim schools for many years and as the number of men who knew them decreased, they became obsolete. To go back to these works now and plunge into their study in order to translate the science of medicine into our own language, Turkish, would be a painstaking job actually requiring many years. ${ }^{23}$

Here Mahmud II makes the assertion that earlier Ottoman medical thinkers, plague treatise writers included, in general had outdated ideas and wrote in classical Arabic, supposedly a language which was foreign to Ottoman Turks and others of the empire's ethnicities. This statement also implies that the Ottomans 
suffered from a lack of print culture and other technological developments that widened the public and scientific reception to new medical ideas.

But one should weigh his statements carefully. Although Bitlisi, Taşköprüzade and Al-Yahudi's works were still in circulation in the early nineteenth century, as is evident from a rise in manuscripts on the topic during Mahmud II's reign, it is ironic that a number of these new manuscripts were in fact translations of texts from Arabic to Ottoman Turkish. These translators included Ahmed Kürkzade, a prominent early nineteenth-century Ottoman notable from Istanbul, and Muhammad Salih, a major figure within the Nakşibandi tarikat from eastern Turkey and an important player in the imperial political scene after Mahmud II had deposed the Janissaries and the rival Bektaşi tarikat. Both translators believed that their efforts were important to ongoing discussions about plague and other epidemic diseases, such as cholera, which had broken out at roughly the same time period. ${ }^{24}$ If Mahmud II saw these works as a waste of time and effort, a number of other participants in Ottoman literary culture fundamentally disagreed.

Nevertheless, one should not underestimate the impact Bitlisi, Taşköprüzade, Al-Yahudi and the other early modern Ottoman authors had on audiences from the late fifteenth to the mid-seventeenth centuries. They were indeed aimed at a variety of circles, including religious and urban elites, Ottoman statesman and court circles. Many in this audience were fluent in classical Arabic: a legal and ecclesiastical language used in many ways like Latin in much of central and western Europe. Moreover, a considerable number of readers who saw the works in collections in Istanbul and other regional cities (for example, Damascus, Cairo and Salonika), doubtless passed on what they read to third parties. They could have conceivably read them to others or summarised them orally. They could have conveyed these ideas in an institutional setting, such as an Islamic school (medrese or mekteb), a local judge's court, at a local mosque or pious foundation, at market or even on the street. Some ideas may even have penetrated emerging coffee houses, where minstrels could talk of some materials, like Bitlisi's adventures, as a traveller's tale. Certainly, the works did not have the benefit of a printing press, but such a medium did not begin to have a full impact on medical and scientific developments until the overseas commercial developments of the mid-seventeenth century. ${ }^{25}$

One should also note that a number of the key plague treatises - such as Taşköprüzade's and two anonymous seventeenth-century works - were translated at that time into Ottoman Turkish by highly respected members of the literary elite, such as Ebussuud Efendi, the single most influential Ottoman Islamic jurist of the sixteenth century, and Abdulgani Efendi, a well-known seventeenthcentury religious figure. Although much of the early modern literature on plague 
remained in Arabic, their translations helped to sow the seeds of Ottoman literary culture. ${ }^{26}$ This mixture of vernacular with ecclesiastic languages is a familiar one, considering that a similar discourse was witnessed in Europe at that time. ${ }^{27}$

In retrospect, one may first conclude that Muslim treatise writers, and the Ottomans in particular, exchanged new ideas on all aspects of the plague from the Black Death of 1347-8 until the late sixteenth century. In this regard there was no major difference between European and Muslim authors. The question of whether Muslims and Europeans had differing popular reactions is still open, but the frequent suggestions of contagion, fleeing and even Al-Yahudi's hint that isolation was justified may be evidence of similarity on many fronts. One can say with relative certainty only that historians have generally overstated the case that Europeans alone reacted to plague with measures based on experience and scientific observation.

It is also difficult to make geographic or comparative notions about the dissemination of knowledge and the origins of disease. One frequent thread in the history of knowledge maintains that any innovation in Muslim civilisations was due to the 'importation' of that idea from Europe. Edward Gibbon, for example, goes so far as to claim that the Abbassid translators of ancient Greek texts into Arabic were Christian Greeks and that the Arabs themselves distained learning a heathen tongue..$^{28}$ Yet such arguments cannot adequately explain how other writers, like Bitlisi, could succeed in introducing new medical ideas, since he was not of European origin and did not even travel to non-Muslim lands. How could a Muslim so freely exchange thoughts on combating plague that were in vogue in Europe at the same time, if there was not an intricate and ongoing cultural, social and intellectual exchange between the two cultures?

Instead, the focus should be on the multicultural experience of many of the plague treatise writers. Al-Yahudi, the Sephardic Jewish refugee, found his counterpart in Bitlisi, who likewise fled as a Sunni Muslim from religious persecution by the Twelver Shiite, Ismail Shah. As seen in Chapter 5, it is no mistake that these two scholars would be joined in the nineteenth century by Hamdan, an Algerian who fled French colonisation in the 1830s. ${ }^{29}$ Each of these authors' exposure to foreign cultures may well have led to greater openness to novel conceptions of plague, preventative measures and prescriptions. Among the early Ottoman treatise writers, one can see this tendency when Al-Yahudi cited Christian doctors who prescribed untraditional, seemingly prohibited cures like alcohol, and when Bitlisi made a pitch for quicksilver, a non-Galenic chemical treatment. ${ }^{30}$

Strikingly, the comparative notion of judging an 'other' civilisation as the origin of an epidemic disease was also not limited to European authors. Admittedly, even the ancient Greek Thucydides, the fabled 'father of history', 
contended that the plague that struck Athens in 430 BCE originated in East Africa and travelled to Greece via Egypt and Persia. ${ }^{31}$ Fourteenth-century European writers likewise believed that the Black Death came from central Asia. ${ }^{32}$

In contrast, Bitlisi claimed that syphilis came from Europe. Such a claim may well have stemmed from a shared dialectical tradition of 'otherness' that went back to the ancient Greeks, but the growing exposure between various global cultures must also have played a role. Syphilis indeed broke out during a time of transatlantic travel and the beginnings of European expansion. Just as the Ottomans would blame syphilis on the Europeans, so too the Europeans asserted that syphilis originated in America. This multi-layered discourse reveals that such writers conveyed their own biases, comparing one 'civilisation' with another. This comparative approach developed even further in the late eighteenth and nineteenth centuries, when reformers and/or colonist-minded European thinkers often contrasted their own 'progressive' 'modern' agenda with that of the 'backward' past. Thus, 'facts', 'witness accounts' and 'observations' about the origins of disease, or how one should react to it, have a long history of being socially constructed. Seemingly, ancient Greeks, Western orientalists and Muslim innovators have all been more than happy to construct such myths. ${ }^{33}$

\section{QUARANTINES AND MERCANTILIST DISCOURSE}

The development of quarantines among the maritime powers of Europe in the seventeenth and eighteenth centuries was pivotal to changes in medical treatise discourses on plague. These states adopted contagionist measures as part of a general mercantilist policy of state-led commercial and economic reforms aimed at controlling overseas trade routes by monopolising markets in which they would import raw material goods, export manufactured products and maintain a favourable balance of trade. ${ }^{34}$ Such states, particularly Britain, Holland and France, began by developing their navies of 'ships of the line', seaworthy, ocean-going vessels with the most up-to-date cannonry, as well as their merchant marines of new, flat-bottomed sailing vessels that allowed for a far greater volume of bulk goods. These states thereafter initiated a series of reforms - establishing monopolistic trading companies, levying tariffs against foreign goods, subsidising overseas commercial commerce, promoting new credit institutions - in order to achieve their agenda. ${ }^{35}$

Establishing quarantines helped to justify these policies of state intervention, particularly in the Ottoman Empire, which many Europeans imagined being as plague-ridden since the 1347-8 outbreak passed through Constantinople and Cairo. It was no accident that the quarantine official who met the trading vessels on the docks, was also frequently charged with taking customs and enforcing 
trade monopolies. Mercantilist states often exercised sovereignty by controlling the economy in the name of public health. ${ }^{36}$

The plague treatise writers who debated quarantine and other preventive measures in a mercantilist context played a fundamentally different role to that which they had previously. Beforehand, plague treatise writers were tied to relatively limited court and academic circles. Some, like Fracastoro, may have entertained the idea of contagion, but they did not translate those ideas into institutions. For example, Italian city-states like Venice, Genoa and Leghorn may have regularly quarantined vessels for up to forty days from the late fourteenth to the sixteenth century, and in about 1600 may have even developed public health offices, permanent lazarettos and cadastral records of the plague dead. But there was no broad debate in print involving said state officials, plague thinkers and the merchant community. In sum, literary elites remained aloof from popular and state efforts at quarantines, even in the decades after Fracastoro's death.

Once the quarantines were established in the Atlantic mercantilist communities of north-western Europe, new commercial interests began to question the efficiency of such measures - especially if they perceived quarantine to be eating into their profits. Medical treatise writers often themselves participated in merchant ventures or were partisans of state reforms. In either case, the writers and their works aimed at this newly emerging public sphere. It was at this time that the writers first really made use of printed books, pamphlets and commercial gazettes to sell their ideas to their rapidly expanding readership. ${ }^{37}$

One really witnesses the beginning of such debates in London during the seventeenth and eighteenth centuries, when plague treatise writers began to participate themselves in formulating new state policies on plague, trade and overseas commercial ventures. One can see this, for instance, when members of the College of Physicians, such as Dr Richard Mead, called for quarantine measures and met responses from state officials, like Sir James Porter, long-time British Ambassador to the Porte, members of the merchant community, such as the British Levant Company's Dr Patrick Russell, and even reformist-minded critics, like John Howard. ${ }^{38}$ London's commercial elites and booming urban economy were dependent on a powerful navy and merchant marine opening the way for overseas trade, such as with the Ottoman Empire. Their overseas trade with such places certainly played a great role in generating new wealth, particularly by providing an emerging British textile industry with bulk goods, such as cotton, wool, flax and silk. However, they also brought new public health problems to the fore. Extensive contacts with distant foreign lands were a conduit for dangerous new epidemics. Advocates of quarantines did not forget that most European accounts of the Black Death claimed that the disease came through the eastern Mediterranean and Constantinople, after it first broke out in central Asia. More 
recent literature on syphilis pointed to the European exploration of America as a cause for epidemics. The numerous Native American deaths the Europeans saw from smallpox were just one reminder of this trend. They also were aware that the drawbacks of London's rapid urban growth - congestion, filthy conditions, immigration and social change - often could also foster disease and death. Many saw these developments as the causes behind the plague of 1665 , and the great fire that followed it in $1666 .{ }^{39}$

In response, English statesmen and politicians began to take new protectionist measures in order to address these concerns, thereby promoting the country's commercial and demographic development. Some of these measures, like the Bills of Mortality, which calculated London's death rate, satisfied both the statesmen and the merchants. On the one hand, the Bills were seen important for determining to what extent plague endangered the population, and led to possible preventative measures (for example, travel restrictions, quarantine and sanitary improvements). In fact, John Graunt attempted to write the first statistical survey of London based on these figures in 1661. This work and others like it would lay the groundwork for later demographic studies, better known at the time as 'political arithmetic'. On the other hand, the Bills led to greater commercial development, since they allowed people to draw up life insurance based on the death rate. This provided investors with greater financial security, and holders even began to use their policies as a form of paper currency. This helped to alleviate England's dependency on precious metal coinage, a major problem in all early modern economies. It also paved the way for even greater developments, such as stocks and bonds which fuelled London's rise as the world's pre-eminent financial capital, and the headquarters of commercial and industrial revolution. ${ }^{40}$

Quarantine restrictions relating to trade would prove to be far more controversial. The Royal College of Physicians recommended as early as 1636, that:

care be taken that neither man nor goods may come from any suspected places beyond the seas, or in the land, without a certificate of health, or else either to be sent suddenly away, or to be put to the pest-house, or suchlike place, for forty days (according to the custom of Italy). ${ }^{41}$

In times of emergency, such as London's Great Plague of 1665, royal authority enforced such quarantines. Merchants might have protested the measure, but were reassured that it would be dropped after the plague subsided. ${ }^{42}$

After the plague broke out in Marseilles in 1720, the Royal College of Physicians, having now gained greater standing as a state institution, pushed for a permanently enforced quarantine. The main culprit, they maintained, were imported goods from the Ottoman Empire, including cotton and flax (from Cairo 
and Syria), wool (from central Anatolia) and silk (from Bursa). Not accidentally, these items made up the bulk of England's Levant trade, and were key to her textile industry. ${ }^{43}$ Dr Mead, the chief author of the measure, saw:

that of all the goods which harbour infection, cotton in particular is the most dangerous, and Turkey is almost a perpetual seminary of the plague; I cannot but think it highly reasonable, that whatever cotton is imported from that part of the world, should at all times be kept in quarantine; because it may have imbibed infection at the time of its packing up, not withstanding no mischief has been felt from it by the ship's company. ${ }^{44}$

England's commercial elites, particularly Levant Company partisans, bitterly protested this restriction, arguing that the merchants and sailors involved in the trade would surely have been the plague's first victims if cotton, and other like porous items, were indeed infectious:

The merchants who have lived in Turkey can inform us, that after the plague has ceased, they, or their servants, do handle and smell the cotton etc. without receiving any injury. Every one who has been in Turkey well knows that stevedores and sailors often work naked, in stowing the cotton. This is a laborious employment, and the hold of the ship is excessive hot. Further, the cotton packs or bales are continually handled and tumbled about; the labourers too are often bare footed, therefore they cannot help treading continually on the merchandise brought aboard. ${ }^{45}$

Others asserted that the plague was never transmitted in England from the Ottoman Empire, as it was endemic to that country alone:

Has not merchandise been brought from many parts of Turkey, all which have very deservedly an ill name for the pestilence, that very commonly rages among them? And how comes it to pass that during this constant, and uninterrupted commerce, when soft and porous goods, the proper somes, have been brought from Smyrna, Iskenderun, Aleppo, Constantinople, and other parts, the pestilence has never taken a journey hither, in all appearance, those fifty-five years [since the Great Plague of 1665] ${ }^{46}$

There were even some who claimed that the quarantine of goods could spell the end of England as a mercantile power:

The Venetians (says a certain author) were long possessed of the profitable Turkey trade, and were almost the only merchants that traded into Turkey, 
and furnished the western parts of Europe with this merchandise; in all that time they had no notions of the frequent plagues being conveyed in goods they brought home, and were transported into other nations. And it is very remarkable, that about the time they instituted officers of health, and begun the practice of quarantines ... their trade fell sensibly into decay. Our merchants about the same time made experiments of the Turkey trade, and became proselytes to this Turkish opinion, that a plague is not conveyed in goods. ${ }^{47}$

This passage illustrates the fear that quarantines established in England would be a devastating public expense and bureaucratisation that would kill trade and play into the hands of the country's commercial rivals.

Parliament ignored most of these protests when it passed Mead's Quarantine Act in 1721. Although they did not establish lazarettos in England proper, British government officials, acting through their Ottoman consulate, would judge whether a quarantine of varying lengths needed to be carried out at a number of Mediterranean ports (for example, Malta, Ancona, Messina, Venice, Leghorn and Marseilles). If there were no rumoured or confirmed cases of plague, the British officials could issue a 'clean bill of health' meaning that the ship would either be exempt from quarantine or only required to wait up to two weeks in one of the lazarettos. However, if there were concerns about plague, the British Consul would issue a 'foul bill of health', requiring a full quarantine of forty days. ${ }^{48}$

New protests soon circulated against these measures. Some, like James Porter, a former British Ambassador resident in Istanbul, stated categorically that he had never heard of plague affecting any of his countrymen:

There is not, indeed, upon record, nor has a single living witness ever related an instance of an English factor, or servant's dying of the plague at any of the seaport towns, or in any other part of Syria, or Asia Minor, but only one at Constantinople, in almost a century; though the disease frequently rages in that metropolis. ${ }^{49}$

Such statements may have led to arguments about the innate superior health of the British, or perhaps the benefits of the British diet or hygiene. The main point, however, was that the British should waste no time bothering about contagionist measures, as it would only hurt the Levant Company's profits.

Others claimed that the methods used for quarantining merchandise, such as the airing of cotton, actually damaged the product. John Howard, the late eighteenth-century reformist who generally advocated for stricter quarantine measures, admitted this himself: 
The cottons are taken out of the bags containing them, and placed in rows of piles, upon boards lay down on stone pillars about 18 inches from the floors; and in repacking they are flung over a man who gets into the bags, in order to tread down the cotton; the consequence of which must be exposing him to greater danger should any infection remain. This, though the surest way of expelling infection from cotton, is not the most agreeable to merchants, not only because more expensive, but also [because it damages the merchandise]. ${ }^{50}$

Yet another popular argument among the merchants was that the Levant Company and the local consul needed no further governmental supervision after loading in port. Porter argued, for instance, that the merchants took extremely vigilant measures to protect themselves from the epidemic disease:

All communication of the infection must arise either from men or merchandise; with regard to the former, when there is the least suspicion of plague in any seaport town of Turkey or any neighbouring village, the master of ships, the merchants, and the consul are particularly careful and vigilant to keep the vessel at a proper distance in the port, and not to suffer any of the ship's company to go on shore; at the same time they will not permit a living soul to come aboard, or any good susceptible to infection to approach the vessel. All seamen are strictly forbidden to go near it; and, to do them justice, they punctually obey the order: for when the fear of that disease is once infused into their minds, they dread it more than a wreck, or a cannon ball..$^{51}$

Porter's logic here was that a merchant ship's crew were well aware that the journey from the Ottoman Empire to England would take at least two months. Plague would rapidly spread in the stagnant air of the ship's cabin, typically killing from a half to two-thirds of the crew before arrival..$^{52}$

Also popular, of course, were appeals to British patriotism. Porter lauded his own countrymen's survival instincts as a supreme virtue:

The desire of self-preservation is as strongly implanted in the breast of an Englishman; it actuates him as powerfully abroad as at home; he would not surely venture the loss of his life by infection, if there were the least grounds for such apprehension. ${ }^{53}$

Such statements would seem powerful, especially given the sentiments of many Members of Parliament who would decide on the matter, since they too were sympathetic to commercial interests, often holding stocks or participating in the trade directly. ${ }^{54}$ 
John Russell, himself a factor of the Levant Company, and, interestingly, a doctor of medicine who supported Mead's Quarantine Act, stopped short of accusing his fellow merchants of reckless greed:

He must entertain an ill opinion of mankind who can believe any merchant, in the Levant, from lucrative motives, would risk the health of his country, by exporting merchandise when the plague was raging in the place; or under the conviction of his own mind, that his commerce, highly advantageous as it might be to himself, might in the event involve thousands of his fellow creatures in misery. ${ }^{55}$

Patriotic appeals reached their height when it came to trade rivalries, however. The English merchants almost invariably compared their own trade with that of the Dutch, whose merchant marine and commercial economy competed with the English throughout the seventeenth and early eighteenth centuries. The Dutch were the undoubted pioneers of free trade and were even more reluctant than the British to adopt quarantines. James Porter jealously argued that:

The Dutch never receive the contagion directly from thence [the Ottoman Empire]; they have admitted ships into their ports, either with clean or foul bills of health, and found themselves, as we may, always safe..$^{56}$

Howard took an entirely different tack when he blamed the great plague of 1665 on these free-wheeling Dutch traders:

I do not hesitate to affirm, from the fullest authority of undeniable testimony, that it first entered this island by means of contagion, and was brought from Holland in merchandise imported from that country, where it had made great ravages the preceding year; and if anyone is desirous of inquiring further into its origin, I inform him, that if any credit is to be given to report, its seeds were brought into Holland from the Turkish empire, along with cotton, which is a most faithful preserver of contagion. ${ }^{57}$

Howard's argument was highly provocative, given the growing importance of Levant cotton in the late eighteenth century. When Mead first pushed for his Quarantine Act in 1720, cotton was not nearly as important to the Levant Company, as their import trade favoured silk, followed by other raw material commodities like cotton. The British cotton textile industry was only just developing at that time, and its demand was largely met by American and Caribbean cotton producers. When Howard wrote in 1787, the situation had dramatically changed. The newly independent United States, along with their French and 
Spanish supporters, did not guarantee the British unfettered access to their colonial supplies of cotton at a time when demand was soaring. Rapid technological improvements in the 1770s and 1780s transformed England's cotton textile production into one of the main engines of the Industrial Revolution. ${ }^{58}$

Howard furthermore claimed that the Dutch refused to build their own lazaretto to protect the public:

When representations were made in Holland on the necessity of establishing a lazaretto to obviate this risk, and the fatal consequences which the introduction of the plague might be to all of Europe; but perhaps the Hollanders, ever preferring the interests of their trade to those of humanity, would not allow so forcible an argument to have any weight with them; but gave for answer, that it would be time enough to think of a lazaretto when English had built one. ${ }^{59}$

This picture took on an even more sinister tone when one considers the Dutch outsourced up to three-quarters of their cotton trade to the Ottoman Greek minority, who were granted the right to fly the Dutch flag on their trading vessels. ${ }^{60}$ The Greeks, who made up a substantial community in almost all the major Ottoman ports, would often give:

False reports concerning the plague ... Their deputies inform consuls of accidents having happened in their nation, when in reality there is no plague in this city or its environs. ${ }^{61}$

Such criminal activity would depress their British rivals since they would have to:

Perform a long and expensive quarantine in the ports of the Mediterranean, by which means the cottons which form their principal loading, as well as the chief article of both trades, are no less than seven months on their way to London. ${ }^{62}$

In contrast, the Greeks could quickly move their ships to Holland, where they would perform a minimal quarantine, if at all. All told, the Greek ships could deliver their cargo at least two to three months before their British rivals. This allowed the Dutch to supply more than half of the Ottoman cotton to London. Thus, the British quarantine would be compromised by lax Dutch measures and potentially contaminated cotton. ${ }^{63}$ At least some of the supporters of the 1721 legislation, such as Daniel Defoe, had this loophole in mind, as it supported the Channel and Atlantic cotton trades at the expense of the Levant Company. ${ }^{64} \mathrm{By}$ the 1780s, this favouritism was no longer in the national interest, since the War 
of American Independence had cut England off from French, American and Caribbean supplies. ${ }^{65}$

John Howard's answer to this conundrum was to establish a permanent lazaretto in England, which all arriving ships would have to undergo. He also called for a ban on third-party cotton trade, which in effect meant a shipping monopoly for the Levant Company, since the Navigation Acts strictly prohibited foreign vessels from trading in English ports. Howard sought the measures in order to secure the country's public health by limiting the risk to plague; but he also argued that they would have a profoundly positive effect in promoting British trade:

In what a different situation would the establishment of a lazaretto put it? By depriving the Dutch of the advantages they now enjoy, we should be able to supply the whole quantity of cottons demanded at our market; instead of only sending 5,000 bales, we should send more than double that quantity annually; and as by a fixed regulation of the Levant Company, we can only purchase the products of this country with the produce of goods sent from England, the importation of our manufactures would increase in the same proportion. The quantity of shipping employed in the trade would likewise be doubled, and by earning the freight which is now paid to the Dutch, on the cottons they sent to England, it would be so much clearer gain to the nation, added to the advantages which would attend the extension of its navigation, an increase of the consumption of its manufacturers; advantages which are now enjoyed by our rivals the Dutch, the prosperity of whose trade is founded on the ruin of ours. ${ }^{66}$

The argument that a mandatory national lazaretto would double British cotton shipments and increase exports assumed British textile factories would continue to flood the market even after implementing the quarantine. Regardless of the uniformity the measures might create in terms of regulating the trade, the lag time of up to seven months per shipment would not change. ${ }^{67}$ Nevertheless, the British did not have to worry about foreign competition, since their navy ruled the Mediterranean after Admiral Horatio Nelson's defeat of Napoleon's fleet at the Battle of the Nile in 1798. Likewise, the national interest would not be harmed if British textile factory owners abandoned the Ottoman cotton market for India, where the British East India Company largely dominated cotton production. ${ }^{68}$

In general, mercantilist plague treatise writers - both quarantine advocates and opponents - were much more connected to the public sphere, particularly with regard to commercial and trading interests. In 1665, Dr Hodges speculated that Dutch imported cotton caused London's Great Plague, an easy enough argument when the English were in the midst of a war with the Netherlands. ${ }^{69}$ In 
1720, Daniel Defoe would condemn the Levant Company and Dr Mead would claim that the Ottoman Empire was the seminary of the plague; both played key roles in shaping quarantine legislation that favoured non-Levant trading interests. Similarly, mandatory lazarettos were established by 1788 in part to secure new sources of cotton and further nationalise trade. ${ }^{70}$ Yet, from the 1670s onwards, there was not a single plague death recorded in London's Bills of Mortality. ${ }^{71}$ It would seem that profit rates, not death rates, were the bottom line to quarantine reform discussions.

\section{AN OTTOMAN RESPONSE?}

The issue to consider, then, is why the Ottomans did not adopt a quarantine until the 1830s. One might expect the Ottomans to have developed initial measures as early as the sixteenth century, given the concentration of plague writers, undoubted social and administrative innovations, and their proximity and interaction with Venice, Ragusa and other Italian city-states that had started quarantines of their own. At least one European observer, Ogier Ghiselin de Busbecq, the Holy Roman Empire's ambassador to Istanbul between 1554 and 1562 believed that the Ottomans dogmatic resistance to innovation explained this discrepancy:

The populace at large rejected the idea of contagion on the grounds 'that the time and manner of each man's death is inscribed by God upon his forehead; if, therefore, he is destined to die, it is useless for him to try to avert fate; if he is not so destined, he is foolish to be afraid'. ${ }^{72}$

There is also no evidence of quarantine reform among the vast numbers of cadastral records governing land, revenue and administrative control during the midsixteenth century, even though key Ottoman Muslim authorities like Ebussuud were amenable to flight and other medical precautions to avoid plague. ${ }^{73}$

Yet geopolitical factors, such as the Ottoman loss of sea power, also need to be considered. Quarantine reform in Europe was developed in order to protect and promote overseas commercial trade, but had no relevance to the Ottomans after they had largely ceded control over much of the Mediterranean, Red Sea and Indian Ocean and made no efforts to match the European expansion into the Atlantic and Pacific. The Ottomans, in contrast to European powers like the English, could not use a substantial merchant marine to modernise its economy and create new commercial links which increased wealth and, incidentally, biological links with the outside world. ${ }^{74}$

Overseas European merchant communities in the major Ottoman ports of Istanbul, Izmir, Beirut and Cairo began to impose their own quarantine. For 
example, Alexander Russell, a British trader to the Ottoman trading hub of Aleppo wrote in 1744 that:

Next to the protection of Divine Providence, the means that the Europeans depend upon for their preservation during the time of plague [in Aleppo], consist either in a retreat from the city, or in setting up in their town houses, in such a manner as effectively to prevent all intercourse or communication by which the infection might be received from without. ${ }^{75}$

In Russell's opinion:

The advantages of shutting up, are in that country fully confirmed by experience, so that all the Christians and Jews ... followed the example of the Franks; and even ... the Turks (who on account of an avowed principle of religion, cannot openly adopt the custom). Many of those particularly conversant with Europeans, devise various pretexts for keeping much at home; sometimes they retire to one of their garden houses, as if merely on a party of pleasure; at other times, when their affairs will permit, they make a commercial excursion to some distant city: A journey to Mecca, under the pretence of devotion, is no unusual expedient for avoiding the impending danger. ${ }^{76}$

Such statements led people to believe that it was only the Europeans or 'Franks' who could really regulate health and, by insinuation, good government.

In actuality, the Ottomans actually went further with plague control measures than most scholars give credit for. While they did not have Bills of Mortality or cadastral Books of the Dead as found in seventeenth-century England and Florence, one can see certain tendencies that led in this direction. For instance, Molla Mustafa Ševki Bašeski, a local Ottoman Muslim notable from Sarajevo, chronicles numerous instances of the plague which hit his city in 1746 and the following years. In his book he records the name, number and the profession of each of the victims. Although his work was not a formal record of the city's dead, I would maintain that one might find similar records in other Ottoman urban centres of that era. ${ }^{77}$

As we can see from Dr Richard Mead, the author of the 1721 British Quarantine Act, the Ottoman treatise writers were probably not the only ones to believe in contagion:

The late Mr. Williams, chaplain to Sir Robert Sutton, when Ambassador at Constantinople [from 1710 to 1714] used to relate a story of the same nature told him by a pasha: that in an expedition this pasha made to the frontiers of Poland, 
one of the janissaries under his command died of the plague; whose jacket, a very rich one, had been bought by another janissary, it was no sooner put on, but he also was taken sick and died: and this same misfortune befell five janissaries more who afterwards wore it. This the pasha related to Mr. Williams, chiefly for the sake of this further circumstance, that the incidents now mentioned prevailed upon him to order the burning of the garment: designing by this instance to let Mr. Williams see there were Turks who allowed themselves in so much freedom of thought, as not to pay that strict regard to the Mohammedan doctrine of fatalism, as the vulgar among them do. ${ }^{78}$

Ironically, Mead cites a Turk as an example to his British audience, especially given his belief that the Ottoman Empire was 'the seminary of the plague'. ${ }^{79}$ Moreover, the fact that the pasha supposedly related the tale to Mr Williams indicates the possibility that key Ottoman notables and statesman might have implemented quarantine reform if given the chance.

An anonymous British writer soon shot back a counter-argument:

Where should be the wonder, to see several people dying in the same coat, in times of pestilence. It is really no more than if several men became heirs to the same estate, one after another successively, as the Turks reason. The true state of this question is, whether the men had the plague before they put on the coat? Or that they died by putting it on? The last is impossible; because of the suddenness of the death, and supposing them otherwise in good health: and the former is the case common enough in times of pestilence, as we may learn by making a voyage to Turkey; where we may find coats of all sorts, belonging to many masters, without describing the cause of their death to the habit. ${ }^{80}$

Here the author posited that most Turks realised the non-contagious nature of plague. Like Mead, he also cited the Turks in high regard, in contradistinction to many negative comparisons, particularly in the late eighteenth and nineteenth centuries. He also indicated the increasing contagionist/anti-contagionist debate, and that Turkish anti-contagionists should not be simply seen as vulgar fatalists as Dr Mead asserted.

One instance where the anti-contagionist belief in the environmental, miasmatic nature of plague led to new innovations was in sanitary reforms. For instance, Ahmed Efendi, an Ottoman astrologer, related the following story about the plague and Istanbul's city planning in 1708:

One day after an earthquake the Sultan gathered philosophers together and asked them how they could stop it. The learned men said that they could solve the 
problem but that the solution would cause plague. By building underground reservoirs (sertablar) you could prevent earthquakes since the fumes would gather there. Wells are also vulnerable to this. The reservoirs, however, would generate fetid air, which would result in plague. The Sultan responded that it was better to have this solution since outbreaks of plague were better than earthquakes. You could cure plague with medicine but an earthquake would kill up to a hundred thousand and damage the buildings. Now days few of these underground reservoirs are left. ${ }^{81}$

This story is evidence that earthquakes and fires were seen by the Ottoman sultan and the authorities as a greater danger to the city than plague. Nevertheless, the later improvements that were made, such as fresh running water, were seen as preventing plague. This is not dissimilar to sanitary movements that you would see elsewhere, such as in London after the Great Fire of $1666 .{ }^{82}$

One outside admirer of Ottoman sanitation was James DeKay, a gifted American traveller who resided in Istanbul in 1831 and 1832 and who acquired an extensive knowledge of the language, culture and society of the people there. DeKay was greatly impressed by the Ottoman capital's water works in comparison with cities in the United States:

Every stranger is struck with numerous contrivances around Constantinople for supplying it with pure and wholesome water. Belonging to a city in the United States which has long been distinguished for its nauseous and detestable water, and for the culpable negligence of its rulers on a subject of so much importance, no opportunity was neglected to obtain all the information in our power in regard to the hydraulic establishments in this neighborhood. The result, however mortifying, must not be concealed, and we therefore state, that on a subject intimately connected, not only with the comfort, but with the health of the people, the commercial emporium of the United States is some centuries behind the metropolis of Turkey. ${ }^{83}$

He later concluded that Istanbul's waterworks must be at least 50 miles long and worth more than $\$ 50$ million (in 1831). In contrast he also asserted that:

The City of New York, with a population of more than 200,000 inhabitants, has been deliberating for years over the question - whether it is expedient to spend two millions of dollars for the purpose of introducing a copious supply of pure and wholesome water. ${ }^{84}$

DeKay made several important observations about the commitment of the Ottoman government to public health. First he claimed that the Ottoman state 
maintained a strong and continuous effort to maintain the water works. A separate governmental supervisor, and even the head of state often exercised direct control:

So important are these watercourses considered that the sultans have always been in the habit of making annually a formal visit of inspection, which is accompanied with much ceremony, and ordering such improvements and alterations as are deemed necessary. ${ }^{85}$

DeKay extensively described a water reservoir. He indicated that there were many such constructions in the mid- to late eighteenth century, which again substantiates Ahmed Efendi's earlier story. One should also note, however, that the water works were also substantially developed from 1550 to 1560 , when the population of Istanbul grew from 150,000 to 600,000 . There is extensive documentary evidence that a water inspectorate was founded to regulate the water works. Still, the Ottoman bureaucracy often had to maintain a careful balance between their desire for regularising control over the capital and the popular push for greater rights and privileges over this precious resource. ${ }^{86}$ This political tension was contrary to DeKay's contention that the sultan exercised absolute control of the water.

Nevertheless, there is much to be said for DeKay's observations on innovating the waterways. He, unlike many Western visitors, credited the Ottomans with improving the city. In contrast to the Roman and Byzantine aqueducts and reservoirs, which at the time he wrote had long 'gone into disuse, as expensive and inadequate for the purposes intended', ${ }^{87}$ the Ottomans had invented a system of pipes and pillars that collected running water more efficiently from the hillsides around Istanbul:

They form a striking peculiarity in Turkish scenery, and it was some time before the principle upon which they were constructed was apparent. The water leaves the brow of a hill, and descending in earth and pipes rises in leaden or earthen ones, up one side of this pillar, to its former level, which must be, of course, the summit of the pillar, or sooteray, as it is called by the Turks. The water is here discharged into a stone basin as large as the top of the sooteray, and is discharged by another pipe, which descends along the opposite side of the pillar, enters the ground, advances to the next sooteray, which it ascends and descends in the same manner; in this way the level of the water may be preserved for many miles over a large plain, when an aqueduct would be, from its expansiveness, manifestly out of the question. In the city of Constantinople, the old aqueducts that no longer conduct water in the usual manner, are converted into a series of sooterays, and permits one to examine their structure in detail. ${ }^{88}$ 
DeKay then proceeds to describe the unique features of the invention, with an eye on possibly adopting it back home in the United States:

This ingenious hydraulic arrangement seems to possess advantages which might recommend its adoption elsewhere. As the pressure is thus divided among this series of siphons, the necessity for having very strong and costly pipes is obviated. As they are from 300 to 500 yards apart, the cost is probably much less than by any plan which could be devised, where, in addition to the cost of a canal or a series of pipes, we should be compelled to raise it again by the expensive agency of steam or some other costly apparatus. The frequent exposure of the water to air and light at the summit of these sooterays is another important advantage which cannot be too strongly insisted upon; as it is now well known that nothing tends more to purify water than the presence of these two agents. The arrangement likewise of the basins on the top of the pillars is well adapted for getting rid of much of the matters deposited from turbid waters. Lastly to the descending pipe a small cock is attached near the ground, by which the flocks and herds of the adjoining villages and fields are furnished at all times with a copious supply of water. ${ }^{89}$

While many might look at the DeKay's argument as a fanciful, one should not forget that traveller's accounts often led to a new innovative designs, such as the British adoption of smallpox inoculations after Lady Montagu's description in 1718 of how Turkish village women injected infected tissue into their veins in order to prevent the disease. ${ }^{90}$ Whether DeKay's sooteray was actually adopted in New York after his visit to Istanbul deserves further investigation.

DeKay did not end his account without highlighting the Ottoman state's commitment to the welfare of its people. This was most evident when he saw that no one ruler ever claimed much credit for the water works:

They [the fountains] are frequently decorated with the inscription setting forth the greatness and goodness of Providence, and inviting the weary traveller to make due acknowledgements for the same. Unlike our civilized ostentation, the name of the benevolent constructor never appears on these sculptured stones. The quaint Turkish adage, which serves as a rule of conduct, is well exemplified in this as well as in many other instances: 'Do good and throw it into the sea; if the fishes don't know it, God will'. ${ }^{91}$

This goes to one of his main arguments: namely, that although the Ottomans' belief in the general welfare of their people may have had its basis in the Islamic faith, it was also reflective of enlightened Western values. 
As DeKay's account shows, the Ottomans of the seventeenth and eighteenth centuries were not focused on undertaking quarantine reform. Works by Ottoman plague treatise writers during this time - like those written by Bašeski or Ahmed Efendi - were few and far between. Ottoman statesmen and administrators may have supported public health works, such as Istanbul's water supplies, but this was a sanitary, anti-contagionist measure unconnected with the treatise writers or commercial elites. This trend would change only when the mercantilist European powers who did adopt quarantines began to challenge the Empire's sovereignty in the name of public health.

\section{CONCLUSION}

Indeed, before the development of the mercantile colonialist states European and Middle Eastern Muslim plague treatise writers strongly resembled each other. Muslim writers, from the fourteenth-century Andalusians Al-Khatimah and Al-Khatib to fifteenth- and sixteenth-century Ottoman writers like Al-Yahudi, Bitlisi and Taşköprüzade, were just as receptive to innovation and contagionist thought as their European counterparts, Fracastoro included. That Fracastoro had his work printed rather than relying solely on penned copies does not belie the fact that these Ottoman and European authors still appealed to relatively limited audiences. ${ }^{92}$

Mercantile development, particularly in England, fundamentally changed the equation by commercialising the plague treatise writer and his product. The English plague treatise writer, for example, produced his work with the emerging market of economic ideas in mind. The conflict of contagionist and anti-contagionist thought continued to bear a superficial resemblance to earlier debates, but the process of social construction was far more subtle. The writer's work was ever more aimed at overseas commercial interests. Remembering Adam Smith, one might postulate that these writers, like the everyday British labourer or business professional, was going through a process of specialisation that would lead to a career as a public health official, state reformer or commercial lobbyist. ${ }^{93}$ Their arguments would either suit the utilitarianism interests of these concerns or risk being discarded. Whether Parliament or the Crown accepted or patronised quarantine proposals, such as Dr Mead's Quarantine Act of 1721 or John Howard's late eighteenth-century proposed mandatory lazaretto, depended upon the market realities of that time. Ideas could change because of many economic factors, such as company monopolies, war, and a growing need for cotton and other 'dangerous' raw material goods.

The Ottoman plague treatise writers between 1600 and 1800 pale in comparison. Not only were there very few new works composed during this time, 
but there also was no comparable drive for mercantilist reform. Ottoman statesmen, like the pasha mentioned in Dr Mead's account or Bašeski, might have entertained ideas of contagionist reform, but they lacked commercial interest and the support of the Ottoman state. ${ }^{94}$ The government undoubtedly made great strides towards improved public health and kept an open mind with regard to innovation, as can seen in the sooterays and the other water-works reforms. Still, the only quarantines in the Ottoman Empire were run by European expatriates and the Greek minority, which apparently also saw the economic utility of the institution. Quarantine also served a useful ideological function for these groups as well: namely, as a marker to distinguish themselves from the fatalistic, barbarian, Ottoman 'other'. Such orientalist discourse would prove to be formidable at the time of European expansion during the early nineteenth century.$^{95}$ It was only when this threat was imminent - as seen in the French invasion of Egypt and Algeria, the British support for an independent Greek state, and the unequal commercial treaty of Balta Liman - that the Ottomans would respond.

\section{NOTES}

1. Giovanni Boccaccio, trans. Guido Waldman, The Decameron, pp. 6-14; Girolamo Fracastoro, De Contagione et Contagiosis Morbis et Eorum Curatione, Libri III, p. 3.

2. Panzac, La Peste dans l'Empire Ottoman, pp. 312-39.

3. Dols, The Black Death in the Middle East, pp. 9-12; David Herlihy, Black Death and the Transformation of the West, pp. 40-1.

4. Boccaccio, The Decameron, p. 2.

5. Boccaccio, The Decameron, p. 3.

6. Herlihy, pp. 71-2.

7. Vivian Nutton, 'The Reception of Fracastoro's Theory of Contagion: The Seed that Fell Among Thorns?', pp. 203-5, 210, 214-16.

8. Anna Campbell, The Black Death and Men of Learning, pp. 50-6, 69-72, 79-86.

9. Campbell, The Black Death and Men of Learning, pp. 66-73, 86-8.

10. Campbell, The Black Death and Men of Learning, p. 57.

11. Dols, The Black Death in the Middle East, pp. 92-4; Ulmann, Islamic Medicine, p. 94.

12. Ulmann, Islamic Medicine, p. 94.

13. Roy Porter, The Greatest Benefit to Mankind: A Medical History of Humanity from Antiquity to the Present, pp. 238-41, 428-9.

14. Vivian Nutton, 'Seeds of Disease: An Explanation of Contagion and Infection from the Greeks to the Renaissance', pp. 1-2, 33-4.

15. Dols, The Black Death in the Middle East, pp. 92-4; Ulmann, Islamic Medicine, p. 93.

16. Bitlisi, Hisn ïl-veba, fol. 29A.

17. Al-Yahudi, Micennetü't-Ta'un ve'l-Veba, fols 11A, 13B-20A; Bitlisi, Hisn ül-veba, fol. 27A; Müstakimzade, Cihazü'l-Macun fi'l-Halas Mine't-Taun, fols 48A-B; Osman, Tercüme-i İthaf, fol. 15A.

18. See Chapter 2, pp. 15-19, 24-8. 
19. Müstakimzade, Cihazü'l-Macun fi'l-Halas Mine't-Taun, fol. 47B; Al-Yahudi, Micennetü't-Ta'un ve'l-Veba, fols 9A-13A, 15A.

20. Derviş Abdullah, Müfredat, fol. 104A.

21. Bitlisi, Hisn ül-veba, fols 27B-28A.

22. Bernard Lewis, What Went Wrong? Western Impact and Middle Eastern Response, pp. 39, 80-1; Bernard Lewis, The Muslim Discovery of Europe, pp. 227-31.

23. Berkes, The Development of Secularism in Turkey, p. 113.

24. Al-Yahudi, Micennetü't-Ta'un ve'l-Veba, fols 1A-B; Bitlisi, Hisn ül-veba, fols 2A-6B.

25. Vivian Nutton, 'Books, Printing and Medicine in the Renaissance', pp. 434-5; Roy Porter, Greatest Benefit to Mankind, pp. 72-4; Sam White, The Climate of Rebellion in the Early Modern Ottoman Empire, pp. 85-7.

26. Ebussuud; Abdulgani.

27. Nutton, 'Books', pp. 422, 432.

28. Edmond Gibbon, The Decline and Fall of the Roman Empire, abridged by D. M. Low, pp. 712-18. Even today, authors like Bernard Lewis make the claim that Sephardic Jewish doctors who fled Spain for the Ottoman Empire, such as Al-Yahudi, brought valuable know-how to a scientifically starved empire. In his eyes, their effect was limited, as they were gradually assimilated into Islamic, tradition-bound ways. Lewis, Muslim Discovery, p. 230.

29. See Chapter 5, pp. 100-12.

30. Al-Yahudi, Micennetü't-Ta'un ve'l-Veba, fols 9A-13A; Bitlisi, Hisn ül-veba, fols 27B-8A.

31. Thucydides, The History of the Peloponnesian War, by Thucydides. A New and Literal Version, from the Text of Arnold, Collated with Bekker, Göller, and Poppo, pp. 30-4.

32. Samuel K. Cohn Jr. The Black Death Transformed: Disease and Culture in early Renaissance Europe, p. 102.

33. Gibbon, Decline and Fall of the Roman Empire, pp. 712-18, 820-32; Lewis, Muslim Discovery, pp. 228-9; Dols, The Black Death in the Middle East, pp. 92-4, 110-20.

34. William Coleman, Yellow Fever in the North, pp. 87-90.

35. Paul Langford, A Polite and Commercial People: England, 1727-1783, pp. 2-7.

36. Panzac, La Peste dans l'Empire Ottoman, pp. 117-8, 129-30; Roy Porter, Greatest Benefit to Mankind, pp. 236-8.

37. Nutton, 'Books', pp. 434-5; Nutton, 'Reception', pp. 232-4; Roy Porter, The Creation of the Modern World: The Untold Story of the British Enlightenment, pp. 72-4.

38. Howard, Account of the Principal Lazarettos in Europe; Mead, A Short Discourse; Mead, Discourse on the Plague; James Porter, Observations on the Religion, Law, Government and Manners; Patrick Russell, A Treatise of the Plague.

39. Campbell, The Black Death and Men of Learning, p. 1; Ralph Davis, Aleppo and Devonshire Square, pp. 13-14; Charles Henry Hull (ed.), The Economic Writings of Sir William Petty: Together with the Observations upon the Bills of Mortality more probably by John Graunt, pp. 1xxx-lxxxii.

40. John Graunt, Natural and Political Observations Mentioned in a Following Index, and Made upon the Bills of Mortality ... by Capt. John Graunt; Nathaniel Hodges, Loimologia: or, an Historical Account of the Plague in London in 1665: With Precautionary Directions against the Like Contagion. By Nath. Hodges, M.D. . . To which is Added, An Essay on the Different Causes of Pestilential Disease; Hull, The Economic Writings of Sir William Petty, pp. lxxx-lxxxvi. 
41. Patrick Russell, A Treatise of the Plague, p. 318, fn. 10.

42. Charles F. Mullett, 'The English Plague Scare of 1720-1721', pp. 484-516.

43. Davis, Aleppo and Devonshire Square, pp. 14-17.

44. Mead, A Short Discourse, p. 13.

45. John Kells Ingram, A History of Political Economy, pp. 94, 99, 72. Patrick Russell, A Treatise of the Plague, p. 315.

46. Explainer, Distinct Notions of the Plague, with the Rise and Fall of Pestilential Contagion. By the Explainer, p. 105; Patrick Russell, A Treatise of the Plague, p. 321.

47. Explainer, Distinct Notions of the Plague, p. 104; Patrick Russell, A Treatise of the Plague pp. 329-30.

48. Howard, Account of the Principal Lazarettos in Europe, p. 28; James Porter, Observations on the Religion, Law, Government and Manners, p. 441; Patrick Russell, A Treatise of the Plague, p. 343.

49. James Porter, Observations on the Religion, Law, Government and Manners, p. 450.

50. Howard, Account of the Principal Lazarettos in Europe, p. 9.

51. James Porter, Observations on the Religion, Law, Government and Manners, p. 442.

52. Patrick Russell, A Treatise of the Plague p. 349.

53. James Porter, Observations on the Religion, Law, Government and Manners, p. 449.

54. Davis, Aleppo and Devonshire Square, pp. 19-21.

55. Patrick Russell, A Treatise of the Plague, p. 368.

56. James Porter, Observations on the Religion, Law, Government and Manners, p. 441.

57. Howard, Account of the Principal Lazarettos in Europe, p. 32.

58. Hodges, Loimologia, p. 30; Charles Maclean, Results of an Investigation Respecting Epidemic and Pestilential Diseases; Including Researches in the Levant Concerning the Plague, pp. 1-7.

59. Howard, Account of the Principal Lazarettos in Europe, p. 28.

60. Howard, Account of the Principal Lazarettos in Europe, pp. 22, 27; Patrick Russell, A Treatise of the Plague p. 361.

61. Howard, Account of the Principal Lazarettos in Europe, p. 27.

62. Howard, Account of the Principal Lazarettos in Europe, p. 27.

63. Howard, Account of the Principal Lazarettos in Europe, p. 27.

64. Daniel Defoe, The History of the Great Plague in London, in the Year 1665 .. By a Citizen, Who Lived the Whole Time in London. To which is Added, a Journal of the Plague at Marseilles, in the Year 1720.

65. Charles F. Mullett, 'Politics, Economics and Medicine: Charles Maclean and Anticontagionism', pp. 224-51.

66. Howard, Account of the Principal Lazarettos in Europe, pp. 28-9.

67. Howard, Account of the Principal Lazarettos in Europe, p. 27.

68. Mullett, 'Politics, Economics', pp. 226, 233, 236-7, 240-3; Panzac, La Peste dans l'Empire Ottoman, 134-45; Howard, Account of the Principal Lazarettos in Europe, pp. 3-5.

69. Hodges, Loimologia, p. 30.

70. Daniel Defoe, The Case Fairly Stated between the Turkey Company and the Italian Merchants; Mead, A Short Discourse, p. 13.

71. Mullett, 'English Plague', pp. 485-6.

72. Lowry, 'Pushing the Stone Uphill?', p. 131.

73. Niccolo Machiavelli, The Prince, pp. 129-35. The conclusion most current day prominent 
scholars of Ottoman science and medicine have reached is that something had dramatically 'gone wrong'. For instance, Heath Lowry's recent article on the Ottoman's reaction to plague even goes so far as to claim that 1517, some three years after Machiavelli's publication of The Prince, was the major turning point in Ottoman history. He claims that Sultan Yavuz Selim's victory over the Mamelukes at the Battle of Çaldıran that year and the consequent incorporation of the key Arabic lands (the Arabian peninsula, Egypt, Syria and parts of Iraq) led to the transformation of the Ottomans from pragmatic rule with a 'loose version of heterodox Islam' to dogmatic Sunni Muslims, 'the recognized leaders of the premier Orthodox Islamic state in the world'. Qualitatively, Lowry would argue that a popularly open-minded attitude towards plague as contagion and flight as an accepted preventative measure would be rejected in the decades to come. Fatalistic inaction would become the rule. Dols, The Black Death in the Middle East, pp. 281-302; Lewis, Muslim Discovery, pp. 128-30; Lowry, 'Pushing the Stone Uphill?, p. 130; Dols, The Black Death in the Middle East, pp. 281-302.

74. Halil İnalc1k with Donald Quataert, An Economic and Social History of the Ottoman Empire, pp. 123, 144-6.

75. Alexander Russell, Natural History of Aleppo, 1742-1744, vol. 2, p. 373; Panzac, La Peste dans l'Empire Ottoman, p. 312.

76. Alexander Russell, Natural History of Aleppo, p. 376; Panzac, La Peste dans l'Empire Ottoman, pp. 333-4.

77. Molla Mustafa Ševki Bašeski, Ljetopis 1749-1804, pp. 6-7, 10, 285-7. I am grateful to Dr York Norman for pointing out this source and translating relevant passages from Bosnian to English.

78. Mead, A Short Discourse, p. 84.

79. Mead, A Short Discourse, p. 13.

80. Explainer, Distinct Notions of the Plague, pp. 111-12.

81. Pertev Paşa, Risale fi İlmi Tilsım, fols 95A-B.

82. Roy Porter, Greatest Benefit, p. 120.

83. James Ellsworth DeKay, Sketches of Turkey in 1831 and 1832, p. 110.

84. DeKay, Sketches of Turkey, p. 117.

85. DeKay, Sketches of Turkey, p. 111.

86. Robert Mantran, 17. Yüzyılın İkinci Yarısında İstanbul, vol. 1, pp. 45-48.

87. DeKay, Sketches of Turkey, pp. 110-11.

88. DeKay, Sketches of Turkey, pp. 115-16.

89. DeKay, Sketches of Turkey, pp. 116-17.

90. Lady Mary Wortley Montagu, Turkish Embassy Letters, pp. 80-2.

91. DeKay, Sketches of Turkey, p. 111.

92. Nutton, 'Reception', pp. 232-4.

93. Adam Smith, The Wealth of Nations, pp. 9-12.

94. Mead, Discourse on Plague, p. 84; Bašeski, Ljetopis 1749-1804, pp. 6-7, 10.

95. Edward Said, Orientalism, pp. 14-15. 